\title{
Komunikasi Therapeutic Community Pasien Penyalahguna Narkoba Dimasa Pandemi Covid-19
}

\author{
Laila Zakiyatu Zahro \\ STAI Bumi Silampari Lubuklinggau, Sumatera Selatan, \\ lailazakiyatuzahro@gmail.com \\ Rama Wijaya Kesuma Wardani \\ STAI Bumi Silampari Lubuklinggau, Sumatera Selatan, \\ aldiscooter7@gmail.com \\ Pasiska \\ STAI Bumi Silampari Lubuklinggau, Sumatera Selatan, \\ bruspasiska@gmail.com
}

\begin{abstract}
This study will examine the Therapeutic Community Communication of Drug Abusing Patients During the Covid-19 Pandemic " at the Karunia Insani Foundation Rehabilitation Center Kab. Musi Rawas, as for the research method used, namely qualitative research whose approach is more to field research, as for data collection techniques through interviews, documentation and observation. Drug abuse patients know all program activities every day and follow disciplinedly This application is carried out during morning meetings, therapeutic community support during the covid-19 pandemic has three directions, namely peer pressure in the form of warnings when making mistakes and providing feedback in the form of solutions and motivation when listening to problems and complaints between drug abuse patients, family visits (visit), namely when families visit drug abuse patients to see the developments that are in them although limited but drug abuse patients feel and happy to be more relaxed, lastly, from the human gift rehabilitation center holding a recreation (outing) once a month, but during the covid-19 pandemic this activity was temporarily stopped and will be carried out again after the covid-19 pandemic did not increase too much.
\end{abstract}

Keywords: Therapeutic Community; Drug Abuse Patients; the Covid-19 Pandemic 


\section{A. PENDAHUALUAN}

Virus corona telah di tetapkan sebagai wabah pandemik global oleh organisasi kesehatan dunia atau world health organization (WHO) sehingga menambah rasa cemas masyarakat seluruh dunia. kasus ini pertama di temukan pada Negara Bagian China, yaitu Wuhan dengan jumlah korban menembus 80.000 lebih lalu peningkatan terus terjadi di berbagai benua pada Per 30 Maret 2020, terdapat 693.224 kasus dan 33.106 kematian di seluruh dunia. Eropa dan Amerika Utara telah menjadi pusat pandemi Covid-19, dengan kasus dan kematian sudah melampaui China. Amerika Serikat menduduki peringkat pertama dengan kasus pandemi Covid-19 terbanyak dengan penambahan kasus baru sebanyak 19.332 kasus pada tanggal 30 Maret 2020 disusul oleh Spanyol dengan 6.549 kasus baru. Italia memiliki tingkat mortalitas paling tinggi di dunia, yaitu 11,3\%.5 (World Health Organization, 2020) ${ }^{1}$.

Awalnya kepanikan hanya dirasakan berbagai Negara China dan sekitar saja namun setelah Pemerintah Indonesia melalui Presiden Joko Widodo yang secara langsung dari Istana Keperesidenan Jakarta, mengumumkan bahwa dua warga Negara Indonesia positif terjangkit virus dimasa pandemi covid-19 usai melakukan kontak dengan seorang Warga Negara Asing yang terinfeksi virus corona, hingga ahirnya membuat Indonesia masuk kedalam peta persebaran virus corona jenis baru atau Covid-19, corona virus Covid-19 global case by john hopkins case. ${ }^{2}$ Sumber utama penyebaran pandemi covid-19 yaitu dari manusia ke manusia, seperti kontak fisik sehingga penyebaran semakin agresif. Transmisi virus korona dari pasien simptomatik terjadi melalui droplet yang keluar saat batuk atau bersin. Selain itu, telah diteliti bahwa virus corona dapat viabel pada aerosol (dihasilkan melalui nebulizer) selama setidaknya 3 jam. ${ }^{3}$

1 Dewi Cahyandari, Shinta Hadiyantina, and Nandharu Ramadhan, "Upaya Pemerintah Daerah dalam Pencegahan dan Penanggulangan Wabah Virus Korona," Cakrawala: Jurnal Litbang Kebijakan 14, no. 1 (June 5, 2020): 77.

2 Helmi Supriyatno, "Darurat PHK Di Tengah Corona," Harian Bhirawa Online, n.d., accessed May 5, 2021, https://www.harianbhirawa.co.id/darurat-phkdi-tengah-corona/.

3 Cahyandari, Hadiyantina, and Ramadhan, "Upaya Pemerintah Daerah dalam Pencegahan dan Penanggulangan Wabah Virus Korona," 77.

Komunikasi Therapeutic Community... Laila Zakiyatu, Rama Wijaya E Pasiska 
Hal ini cukup sulit bagi masyarakat, karena manusia merupakan mahluk sosial yang dalam kesehariannya dituntut untuk melakukan interaksi sehingga setiap manusia tidak terlepas dari komunikasi, baik verbal atau nonverbal yang bertujuan membentuk makna adanya saling pengertian hingga menimbulkan efek seperti perubahan sikap dan tingkah laku, terlebih bagi lembaga kemasyarakatan yang mengharuskan bertemu dengan banyak kelompok induvidu dalam proses penyembuhan psikologi pasien penyalahgunaan narkoba, karena sampai saat ini bukan hanya wabah virus corona yang mengalami peningkatan tetapi juga pada kasus penyalahgunaan narkoba.

Melalui BNN Pemerintah telah banyak melakukan pemberantasan penyalahgunaan narkoba Namun ironisnya semakin gencar pelaksanaan program pemberantasan narkoba semakin banyak juga temuan-temuan yang tak terduga dari pengedaran narkoba, Narkoba dewasa ini bukan hal tabu di masyarakat Indonesia sehingga kasus penyalahgunaan narkoba terus meningkat setiap tahunnya, bahkan anak yang masih duduk di bangku sekolah sudah tidak memiliki jarak dengan narkoba itu sendiri, mereka cendrung memiliki rasa keingintahuan yang tinggi dengan mencoba sampai ahirnya menjadi ketergantungan. fakta di lapangan bahkan menunjukkan 50\% penghuni LAPAS (Lembaga Pemasyarakatan) disebabkan oleh kasus narkoba, hal ini dapat menunjukan bahwa peringatan saja tidak akan cukup untuk menghentikan kasus penyalagunan narkob karena Berita criminal di media massa, baik media cetak maupun elektronik dipenuhi oleh berita tentang penyalahgunaan narkoba. ${ }^{4}$

Pasien penyalahgunaan narkoba tidak bisa diacuhkan oleh masyarakat karena mereka juga merupakan korban dari salah pergaulan, sehingga pasien harus mendapat penanganan khusus akibat penyalahgunaan narkoba dengan mengikuti terapi-terapi secara rutin yang ditangani langsung oleh orang yang sudah ahli dibidangnya, di mana pasien melakukan aktivitas sehari-hari dengan pemantauan ketat para petugas, Dalam proses penyembuhan pasien penyalahgunaan narkoba banyak berbagi metode yang di lakukakan petugas panti rehabilitasi sebagai pedoman untuk kegiatan-kegiatan pasien selama penyembuhan.

Therapeutic community merupakan metode yang digunakan dalam pelaksanaan rehabilitasi. Rehabilitasi berarti pemulihan kapasitas fisik

4 Fransiska Novita Eleanora, "BAHAYA PENYALAHGUNAAN NARKOBA SERTA USAHA PENCEGAHAN DAN PENANGGULANGANNYA (Suatu Tinjauan Teoritis)," Jurnal Hukum 25, no. 1 (May 5, 2021): 440.

Komunikasi Therapeutic Community... Laila Zakiyatu, Rama Wijaya \& Pasiska 
dan mental kepada kondisi atau keadaan sebelumnya. Bagi penyalahgunaan narkoba rehabilitasi merupakan proses yang harus dijalani dalam rangka pemulihan sepenuhnya (full recovery) untuk hidup normatif, mandiri dan produktif di masyarakat. Sedangkan rehabilitasi dalam ajaran Islam adalah islahiyah, yaitu upaya memperbaiki sesuatu agar kembali pada koridor agama yang bernilai maslahat. Kemaslahatan itu sendiri merupakan tujuan dari syariat yang upaya menujunya terangkum dalam kodifikasi hukum Islam. ${ }^{5}$

Metode terapi dan rehabilitasi dengan pendekatan therapeutic community tidak juga terlepas dari komunikasi terapeutik petugas dengan pasien penyalahguna narkoba, hal ini berfungsi untuk menciptakan suasana nyaman bagi para pasien selama program rehabilitasi. komunikasi terapeutik yang dilakukan petugas dapat mengungkapkan apa yang pasien rasakan sehingga petugas dapat memberi solusi atas apa yang dirasakan pasien, hal ini sangat menjurus dengan pendekatan psikologis perspektif perilaku (behavioral perspective) yang diperkenalkan oleh john b.waston "pendekatan itu tidak hanya sekedar alternatif bagi pendekatan instingtif dalam memahami perilaku sosial tetapi juga memunyai alternatif lain yang terfokus kepada pikiran, kesadaran bahkan imajinasi". ${ }^{6}$ Menurut Purwanto "komunikasi terapeutik adalah komunikasi yang dirancanakan secara sadar dan bertujuan dalam kegiatannya difokuskan untuk kesembuhan pasien dan merupakan komunikasi profesional yang mengarah pada tujuan untuk penyembuhan pasien". ${ }^{7}$

Therapeutic Community ini mengusung konsep kekeluargaan sehingga bukan hanya lingkungan panti rehabilitasi saja yang terlibat tetapi juga keluarga ikut mendukung jalannya terapi. Hal tersebut karena melalui keluarga juga penanaman sistem moral dan nilai-nilai positif dapat dibangun untuk pembentukan perilaku positif serta pertahanan diri dari penyalahgunaan narkoba kembali. ${ }^{8}$

${ }^{5}$ Nur Rakhmi Said, Muhammad Thahir Maloko, and Nur Taufiq Sanusi, "METODE THERAPEUTIC COMMUNITY BAGI RESIDEN DI BALAI REHABILITASI BNN BADDOKA MAKASSAR PERSPEKTIF HUKUM ISLAM," Jurnal Al-Qadau: Peradilan dan Hukum Keluarga Islam 6, no. 2 (December 27, 2019): 285.

${ }^{6}$ Nina W. Syam, Psikologi Sosial Sebagai Akar Ilmu Komunikasi (Simbiosa Rekatama Media, 2012), 63.

7 Widyani Tri Yolanda, "REHABILITASI DI PUSAT PERAWATAN PECANDU NARKOBA DITINJAU DARI KOMUNIKASI TERAPEUTIK," Jurnal Ilmu Komunikasi 5, no. 1 (January 27, 2015): 27.

8 Rachmawati Windyaningrum, “KOMUNIKASI TERAPEUTIK KONSELOR ADIKSI PADA KORBAN PENYALAHGUNAAN NARKOBA DI 
Lebih lanjutnya, proses penyembuhan yang dimaksudkan juga terdapat Panti Rehabilitasi Karunia Insani Foundation yang berada di daerah Kabupaten Musi Rawas Provinsi Sumatera Selatan. Yang menerapkan Terapeutic Community dengan komunikasi terapeutik, Berdasarkan observasi awal peneliti berkunjung ke panti rehabilitasi dan bertemu langsung dengan Aldy dan Lubis selaku petugas panti rehabilitasi, dimasa pandemi ini petugas panti rehabilitasi telah mempertegas aturan kesehatan yang berlaku dan lebih ketat dalam penerimaan pasien baru demi menjaga kesehatan sesama kelompok pasien penyalahgunaan narkoba, mereka juga membatasi interaksi antar keluarga dari pasien itu sendiri melalui jejaring sosial media.

Setiap harinya pasien mempunyai banyak kegiatan yang dilakukan secara bersama dan terjadwal secara teratur sehingga pasien dalam proses penyembuhan mengalamai peningkatan positif dari hari ke hari, namun dengan adanya pandemi covid-19 ini maka petugas sedikit mengalami tantangan baru dalam penerapan komunikasi kepada pasien penyalahgunaan narkoba Hal ini menarik untuk di teliti, dimana dalam penerapan therapeutic community ini pasien banyak melakukan interaksi secara langsung dengan petugas dan semua harus tetap berjalan walau di masa pandemi covid-19.

Persoalan tentang komunikasi therapeutic community pasien penyalahgunaan narkoba dimasa pandemi covid-19 pada dasarnya belum ada yang mengkaji, Sekolah Tinggi Agama Islam ( STAI ) Bumi Silampari menjadi yang pertama dalam mengangkat persoalan ini. Akan tetapi sudah ada beberapa karya ilmiah baik yang berupa buku-buku ataupun penelitian, hanya saja objek yang dikaji sedikit berbeda.Untuk membedakan persamaan dan perbedaan dari penelitian terdahulu maka perlu adanya tinjauan pustaka sebagai bahan pertimbangan dalam penulisan karya tulis ilmiah.Adapun penelitian-penelitian tersebut antara lain.

Penelitian pertama ditulis Oleh Rizki Amalia Dengan Judul Kepuasan Pasien Pada Komunikasi Terapeutik Perawat Di Ruang Inap RSUD. Pirngadi Medan. ${ }^{9}$ Penelitian ini bertujuan untuk mengetahui kepuasan pasien pada komunikasi terapeutik yang diterapkan dengan metode penelitian kuantitatif, penelitian ini

RUMAH PALMA THERAPEUTIC COMMUNITY KABUPATEN BANDUNG BARAT," Jurnal Kajian Komunikasi 2, no. 2 (December 1, 2014): 185.

${ }^{9}$ Rizki Amalia, "Kepuasan Pasien pada Komunikasi Terapeutik Perawat di Ruang Rawat Inap RSUD dr. Pirngadi Medan" (2016), accessed May 5, 2021, http:/ / repositori.usu.ac.id/handle/123456789/17982.

Komunikasi Therapeutic Community... Laila Zakiyatu, Rama Wijaya E Pasiska 
menghasilkan bahwa sebanyak 6.8\% merasa tidak puas, 91,8\% merasa puas dan $1,4 \%$ sangat puas. Penelitian ini dijadikan sebagai acuan karena memiliki persamaan dengan peneliti yaitu samasama membahas tentang komunikasi terapeutik yang digunakan dalam penyembuhan pasien. Dengan begitu peneliti mampu menentukan arah penelitian untuk menghindari adanya flagiasi. Lebih lanjut perbedaan yang terdapat pada penelitian ini terdapat pada objek penelitian, dimana penelitian terdahulu menjadikan perawat dan pasien Rumah Sakit sedangkan penelitian yang baru membuat adanya petugas panti rehabilitasi dan pasien penyalahgunaa narkoba sebagai objek penelitian.

Penelitian berikutnya ditulis Oleh Nurul Restiana Dengan Judul Metode Therapeutic Community Bagi Pecandu Narkoba Di Panti Sosial Pamardi Putra Yogyakarta. ${ }^{10}$ Penelitian ini bertujuan untuk mengetahui serta menganalisis penerapan metode therapeutic community serta kelebihannya. Dengan metode penelitian pendekatan deskriptif kualitatif, penelitian ini menghasilkan bahwa terdapat tiga tahap dalam pelaksanaan metode therapeutic community yaitu dimulai dari persiapan, pelaksanaan dan pembinaan lanjut. Relefansi pada penelitian in terdapat pada pembahasan metode therapeutic community yang diterapkan pada penyalahguna narkoba, untuk mencegah adanya flagiasi perlu mentukan perbedaan antara penelitian terdahulu dan yang baru, perbedaannya terletak pada pembahasaan yang hanya mengulas tentang metode saja tanpa komunikasi yang digunakan. Sedangkan pada penelitian yang baru mengulas bagaimana komunikasi terapeutik selama di panti rehabilitasi.

\section{B. METODE PENELITIAN}

Penelitian ini menggunakan pendekatan kualitatif ${ }^{11}$. Penelitian yang dilakukan penulis menggunakan pendekatan penelitian deskriptif kualitatif, karena data yang diperoleh berupa (kata-kata, gambar, perilaku) tidak dituangkan dalam bentuk bilangan atau angka statistik

10 NURUL RESTIANA, Metode Therapeutic Community Bagi Pecandu Narkoba Di Panti Sosial Pamardi Putra Yogyakarta, n.d. 10.

${ }^{11}$ Lexy J. Moleong, Metodologi Penelitian Kualitatif (Remadja Karya, 1989),

Komunikasi Therapeutic Community... Laila Zakiyatu, Rama Wijaya E Pasiska 
melainkan dalam bentuk kualitatif yang memiliki arti lebih kaya dari sekedar angka atau frekuensi. Jenis penelitian lapangan field research sesuai dengan jenis penelitian yang penulis lakukan. Sehingga seluruh bagian yang menjadi penelitian dapat diamati secara tuntas. Penulis langsung kelapangan untuk mendapatkan data yang diinginkan, agar data tersebut terasa lebih obyektif dan aktual. Dengan menggunakan jenis penelitian lapangan field research, pemalsuan data lebih dapat dihindari, sehingga penulis harus mengikuti kegiatan yang dilakukan selama di Panti Rehabilitasi Karunia Insani Foundation.

Data primer yang langsung diperoleh dari sumber data pertama di lokasi penelitian atau objek penelitian, sumber data dilakukan melalui wawancara dan pengamatan di lapangan". Data primer dalam penelitian ini seperti: data observasi dan wawancara Ketua Yayasan Panti Rehabilitasi Karunia Insani Foundation, admin,petugas panti rehabilitasi, serta pasien penyalahgunaan narkoba, Dinas Sosial serta Dinas Kesehata. Data pendukung yang diperoleh dari sumber kedua yang diambil dari obyek penelitian. Seperti: data sejarah berdirinya panti rehaabilitasi, dokumentasi yang ada di panti rehabilitasi tersebut dan arsip-arsip lainnya". Sumber data sekunder ini akan mempermudah peneliti untuk mengumpulkan data-data dan menganalisis hasil dari penelitian ini nantinya dapat memperkuat temuan dan menghasilkan penelitian yang mempunyai tingkat validitas tinggi. ${ }^{12}$

\section{PEMBAHASAN}

1. Penerapan Metode Therapeutic Community Yang Digunakan Petugas Terhadap Pasien Penyalahgunaan Narkoba Dimasa Pandemi Covid-19

Kata metode secara etimologi adalah berasal dari dua kata yaitu meta artinya melalui dan hodos artinya jalan atau cara. Dalam bahasa Yunani metode berasal dari methodos (jalan) yang dalam bahasa arab berarti thariq. Dengan begitu dapat disimpulkan bahwa metode berarti sebuah jalan atau cara untuk mencapai tujuan. Terapy secara etimologi (harfiyah) yang berasal dari bahasa inggris therapy, dalam Bahasa Indonesia dimaknai dengan pengobatan, atau penyembuhan dalam kamus istilah konseling pun terapeutic menunjuk pada sifat yang menyembuhkan dan menyehatkan. Community yang berarti komunitas, kelompok atau masyarakat. Dalam kamus psikologi community adalah hunian manusia yang berkonsentrasi di suatu wilayah geografis. ${ }^{13}$

12 Ibid., 156.

13 James P. Chaplin, Kamus Lengkap Psikologi: James P. Chaplin (Rajawali Press, 1993), 61.

Komunikasi Therapeutic Community... Laila Zakiyatu, Rama Wijaya E Pasiska 
Dari paparan di atas therapeutic community ini dilakukan secara berkelompok hal ini yang mempunyai unsur kesamaan dalam perilaku ataupun sifat hal ini di ungkapkan oleh John Watson "pendekatan tidak sekedar alternatif bagi pendekatan instingtif dalam memahami perilaku sosial tetapi memiliki alternatif lain dalam memahami pikiran, kesadaran bahkan imajinasi"14 john watson juga memasukan perilaku kedalam satu unit (response), dan lingkungan kedalam unit rangsangan (stimuli). Karena satu rangsangan dan tanggapan tertentu akan membuat hubungan baik di antar pasien penyalahgunaan narkoba sehingga dalam proses penyembuhan dengan komunitas, lingkungan, keadaan yang sama akan memberi hal positif tanpa rasa tidak percaya diri.

Lanjutnya Therapeutic community merupakan metode yang dilakukan melalui pendekatan sosial yang dilakukan dalam satu komunitas, sehingga tidak ada komunitas di dalam komunitas hal ini diupayakan sebagai proses penyembuhan pasien satu sama lain yang memang mengalami kondisi yang sama-sama ingin lepas dari Penyalahgunaan narkoba, sehingga kenyamanan pasien selama menjalankan proses penyembuhan sangat di upayakan.

Di masa pandemi covid-19 ini tentunya dalam menerapkan metode therapeutic community harus tetap menerapkan protokol kesehatan yang ada seperti menjaga jarak, mencuci tangan hingga menggunakan masker hal ini juga diharapkan oleh Ari Winarko Selaku Seksi Surveilans, Imunisasi Dan Kesehatan Khusus Dinas Kesehatan Kab. Musi Rawas yang mengatakan bahwa:

"Sebenarnya dalam panti rehabilitasi juga sudah tida ada masalah karena mereka juga telah mengadakan sistem karantina di dalam panti rehabilitasi namun lebih dipertegas dengan penerimaan orang luar yang datang ke sana, jadi diperlukannya cek suhu,tempat penyediaan mencuci tangah dan kewajiban menggunakan masker, karena yang kita takutkan adalah ketika orang luar yang berpergian lalu membawa virus covid-19 tanpa kita ketahui". ${ }^{15}$

Hal ini juga di harapkan oleh Muslimin Selaku Kabid.Rehabilitasi Sosial bahwa :

"kita juga telah berpesan kepada seluruh petugas panti rehabilitasi karunia insani foundation terkait pademi covid-19 ini untuk tetap menjaga kesehatan, terlebih untuk kunjungan

${ }^{14}$ Syam, Psikologi Sosial Sebagai Akar Ilmu Komunikasi, 64.

15 Ari Winarko, "Imunisasi Dan Kesehatan Khusus Dinas Kesehatan Kab. Musi Rawas," November 5, 2020. 
keluarga yang harus di batasi untuk mengurangi pencegahan virus di Panti Rehabilitasi Karunia Insani". 16

Berdasarkan hasil observasi awal peneliti juga mengikuti protokol kesehatan seperti cek suhu menggunakan termogan, mencuci tangah hingga mengunakan masker,begitu juga dengan keluarga yang berkunjung (visit ) di batasi dengan waktu kurang lebih 1 jam bertemu pasien penyalahgunaan narkoba. Therapeutic community pasien penyalahgunaan narkoba ini dilakukan dalam satu atap rumah yang biasa dilakukan dalam menjalankan program, mereka juga menggunakan halaman belakang rumah, halaman depan serta lapangan bola yang tepat berada di depan rumah Panti Rehabilitasi Karunia Insani Foundation sendiri, untuk melakukan segala aktivitas pasien penyalahgunaan narkoba memerlukan fasilitas yang memadai sehingga pasien penyalahgunaan narkoba dapat merasakan kenyamanan dan menganggap sebagai rumah kedua bagi pasien penyalahgunaan narkoba.

Penerapan therapeutic community Panti Rehabilitasi Karunia Insani Foundation terhadap pasien penyalahgunaan narkoba di masa pandemi covid-19 terdiri dari 4 struktur program :

a. Pembentukan Tingah Laku (Behavioral Menegement Shaping)

Pasien penyalahgunaan narkoba merupakan korban dari keganasan zat adiksi yang telah meracuni tubuh baik secara psikis maupun sosial dari pasien panyalahgunaan narkoba itu sendiri. Sehingga ketika mereka telah menggunakan narkoba terlebih dalam jangka waktu yang cukup lama maka pasien penyalahgunaan narkoba akan berdampak pada tingkah laku negatif serta tidak terkendali, mereka juga cendrung menghindari kehidupan sosial yang biasa orang normal terapkan. Untuk mengatasi hal tersebut maka petugas panti rehabilitasi karunia insani foundation membuat sebuah jadwal kegiatan (daily activity) yang harus dilakukan, Kusnadi menjelaskan bahwa :

"mereka disini tidak mempunyai waktu luang seperti melamun atau hanya duduk diam saja, karena disini harus dibiasakan banyak melakukan aktivitas sehingga pasien penyalahguaaan narkoba terbiasa memanfaatkan waktu. Kita juga membuat aktivitas yang berbeda setiap harinya supaya pasien penyalahgunaan narkoba tidak merasakan jenuh. semua hal yang mereka lakukan harus sesuai dengan waktu

16 Muslimin, "Kabid Rehabilitasi Sosial Pada Dinsos Kab. Musi Rawas," October 20, 2020. 
seperti tidur, makan siang bahkan waktu untuk mengonsumsi rokok. Kita menyebutnya dengan sebutan nikotin" ${ }^{\prime 17}$

Dalam kegiatan ini biasanya berada pada program morning meeting, yang dalam programnya setiap pimpinan komunitas yang bertanggung jawab dikumpulkan jadi satu dalam bentuk memutar dan mulai menjelelaskan keadaan diri pada hari itu, apa saja yang dialami, kondisi kesehatan bahkan keresahan apa yang dirasakan pasien penyalahgunaan narkoba, lalu sesama pasien penyalahgunaan narkoba memberi respon (feed back) terhadap perasaan yang dialami pasien penyalahgunaan narkoba

Dalam menjalani program juga pasien penyalahgunaan narkoba diberi tanggung jawab masing-masing untuk mengatur isi rumah seperti pemimpin rumah (leader), asisten (backdase), pecatat kebutuhan rumah (haouse keeping), keagamaan (religius),bagian dapur (kitchen), bagian pakaian ( laundry) kepala team (X- Team ). Ketika mereka telah ditentukan untuk menjadi bagian di atas, maka mereka mmpunyai tanggung jawab utuk memantau apa saja masalah yang terjadi atau hal yang dibutuhkan komunitas.

b. Pengendalian Emosi Dan Psikologi (Emotional And Psychological)

Pasien penyalahgunaan narkoba memiliki kondisi emosi yang tidak stabil bahkan cendrung lebih tinggi, mereka juga terkadang sulit mengepresikan emosi yang ia rasakan selama masa penyembuhan. Sehingga petugas membantu para pasien penyalahgunaan narkoba untuk mengungkapkan emosi nya melalui perkumpulan komunitas yang di padu salah satu petugas yang piket, Hal ini dkatakan oleh kusnadi:

"kita disini hanya memantau permasalahan apa yang terjadi diantara mereka, mereka akan mengungkapkan ketidaksenangan satu sama lain dan memberi respon satu sama lain. teguran ini harus diterima oleh pasien penyalahgunaan narkoba. Jika mereka tidak terima maka mereka akan dikenakan hukuman yang berupa pembelanjaran “.18

Dari pernyataan diatas dapat peneliti simpulkan bahwa, dalam program therapeutic community sangatlah

17 Kusnadi, "Petugas Panti Rehabilitasi Karunia Insani Foundation," October 31, 2020.

18 Ibid. 
bermanfaat ketika petugas sengaja memberi tugas dengan pasien penyalahgunaan narkoba lalu ketika terjadi kesalahan maka antar pasien sesama komunitas lah yang akan memancing emosi bahkan menyebutkan kesalahan-kesalahan kecil yang ia lakukan hal ini dilakukan namun setelahnya petugas akan memberi solusi untuk permasalahan yang dihaadapi sehingga ia sudah mulai terbiasa untuk bisa mengontrol emosi dikemudian hari dan memecahkan masalah sendiri.kegiatan ini diterapkan pada program Grup circle dengan membentuk kelompok memutar oleh seluruh pasien penyalahgunaan narkoba di pandu petugas piket.

c. Pengembangan Pemikiran Dan Kerohanan (Intelektual And Spiritual)

Pasien penyalahgunnaan narkoba yang telah mengenal narkoba maka baik secara fisik, psikis bahkan sosialnya terganggu, maka dari adanya kegiatan seminar untuk menambah wawasan pasien penyalahgunaan narkoba selama proses penyembuha, Hal ini diungkapkan Aldi, "seminar ini membahas tentang pengetahuan mengenai zat adiksi sebagai pengetahuan secara luas pasien penyalahgunaan narkoba dan petugas juga memberikan dampak-dampak yang ditimbulkan, dengan harap mereka aka memahami bahwa setelah keluar tidak akan mengulangi penyalahgunaan narkoba". ${ }^{19}$

Kegiatan seminar ini dilakukan oleh seluruh pasien penyalagunaan narkoba berkumpul di ruangan halaman belakang dengan membawa alat tulis masing-masing, kegiatan seminar ini merupakan proses belajar mengajar. Materi yang disampaikan petugas mengenai zat adiksi, lalu anggota lainnya menulis dan bertanya kepada petugas apabila ada hal yang belum dipahami.

Selain kegiatan seminar pasien penyalahgunaan narkoba juga rutin dalam melakukan puasa senin-kamis sebagai bentuk pertahanan diri terhadap rasa lapar -haus ketika menjalani aktivitas, mereka juga selalu mengerjakan sholat 5 waktu berjamaah belajar membaca Al-Quraan. Kegiatan ini juga memberi perubahan baik seperti yang dirasakan oleh Dedy selaku pasien penyalahgunaan narkoba fase serennity, "rasanya sih nyaman karena semua orang yang

19 Rahman Risaldi, "Petugas Panti Rehabilitasi Karunia Insani Foundation," October 29, 2020. 
ada disini mempunyai kekuatan untuk sembuh. Kami juga disini sudah melakukan sholat 5 waktu yang mana dulu saya tidak teratur alam mengerjakan sholat tapi disini kami di bimbing untuk tepat waktu dalam sholat dan belajar mengaji".$^{20}$ Dari pernyataan Dedy tersebut dapat disimpulkan bahwa kegiatan seminar dan religi yang diterapkan disini sangat memberi efek positif karena dalam mengingat kehadiran Allah swt akan membuat kita semakin takut untuk mengulang hal yang merugikan diri sendiri hingga orang lain. peningkatan kualitas diri dengan menambah wawasan dan ilmu agama merupakan keseimabangan yang pas demi terwujudnya kesehatan lahir dan batin.

d. Keterampilan Kerja Dan Keterampilan Bersosial Serta Bertahan Hidup (Vocational And Survival)

Pasien penyalahgunaan narkoba tidak sedkit yang mengalami masalah dalam mencari pekerjaan, terlebih ketika stigma masyarakat telah negatif terhadap mereka yang menggunakan narkoba, maka dari itu panti rehabilitasi karunia insani juga memberi kepercayaan kepada mereka untuk bereksperimen dengan keahlian yang dimiliki setiap masing-masing pasien penyalahgunaan narkoba, karena ketika mereka keluar dari panti rehabilitasi mereka akan melanjutkan kegiatan seperti biasa. Ini juga menjadi salah satu keinginan dari teguh selaku pasien penyalahgunaan narkoba yang mengungkapkan bahwa," harapan saya setelah pilang dari sini saya ingin bekerja untuk menghasikan uang sehigga dapat membantu keluarga saya. Saya juga ingin hidup normal seperti biasa sebelum mengenal narkoba ". ${ }^{21}$

Pada tahap ini juga pasien biasanya mendapatkan tugas dari petugas yang piket untuk melakukan kegiatan diluar sehingga mereka sudah bisa belajar bersosialisasi secara perlahan, keterampilan ini dapat digunakan ketika pasien penyalahgunaan narkoba dinyatakan sembuh dan dinyatakan mampu untuk kembali hidup normal dan bersosialisasi dengan masyarakat.

20 Dedy, "Pasien Penyalahgunaan Narkoba Di Fase Corge," October 31, 2020.

21 Teguh, "Pasien Penyalahgunaan Narkoba Di Fase Corge," October 31, 2020. 
Penerapan Therapeutic Community Di Panti Rehabilitasi Karunia Insani Faoundation Kab. Musi Rawas melalui empat struktur program juga terbagi dari empat tahap atau fase yakni

1) Tahap induction, atau biasa di sebut dengan tahap detoksifikasi,tahap ini merupakan proses awal yang harus dilalui oleh pasien penyalahgunaan narkoba dimana dalam menjalankan berlangsung slama 7-14 hari dalam masa pemutusan zat. Pada tahap ini pasien belum ikut kegiatan therapeutic community karena tubuh yang lemas akibat detoksifikasi, kegiatan yang mereka lakukan hanyalah makan, mandi, sholat saja lalu masuk lagi ke dalam ruanan detoksifikasi.

2) Tahap ini ditunjukan bagi perkembangan sosial dan psikologis pasien penyalahgunaan narkoba, karena pada tahap ini mereka sudah ikut dalam program Therapeutic Community sesama komunitas. Primary ini terbagi menjadi tiga fase Younger Member Fase ini disebut juga dengan fase orientasi yang berarti perkenalan, dimana pasien penyalahgunaan narkoba harus lebih memahami program (daily activity) sehingga ketika mereka telah memahami program mereka bisa menjadi leader. Biasanya fase ini kurang lebih 2 bulan sudah lewati fase orientasi untuk masuk fase berikutnya, karena setiap program menggunakan bahasa inggris yang membutuhkan waktu lama untuk dihafal oleh setiap pasien penyalahgunaan narkoba.

3) Middle peer Fase ini disebut juga dengan fase serennity yang berarti kedamaian Fase ini lebih fokus pada adiksi dan juga pasien penyalahgunaan narkoba lebih di fokuskan untuk menyelesaikan sebuah masalah. Petugas memberikan tanggung jawab kepada pasien penyalahgunaan narkoba. jika mereka tidak dapat menyelesaikan tanggung jawab dengan baik maka akan ditegur oleh sesama pasien penyalahgunaan narkoba. ketika pasien penyalagunaan narkoba melakukan kesalahan maka petugas akan memerintahkan mereka apa saja kesalahan yang ia perbuat dalam satu hari, hal ini di upayakan agar pasien penyalahgunaan narkoba dapat memahami sejauh mana tanggung jawab dan seberapa benar mereka melalkukan sesuatu. Fase ini juga berlangsung kurang lebih 1,5 bulan. 
4) Older Member Fase ini disebut dengan corge yang berarti keberanian yang Berfokus kepada emosional dan pengetahuan wawasan, petugas lebih di beri tanggung jawab yang lebih besar dari fase serennity, seperti yang dijelaskan Aldi, "tanggung jawab mereka akan meningkat ketika di fase corge misalnya di kegiatan yang cukup padat kami memberi tugas tambahan untuk pasien penyalahgunaan narkoba, dan harus selesai hari ini juga, Maka itu akan memberi tekanan dan pikiran bagi pasien penyalahgunaan narkoba bagaimana untuk menyelesaikannya ".22 Fase ini biasanya berlangsung selama 1 bulan proses penyembuhan. Disinilah peran keberanian ditunjukkan, karena pasien penyalahgunaan narkoba harus berani menyebutkan hal apa yang tidak disukai di antara komunitas atau bebas bereskpresi.

Tahap re-entry atau di sebut dengan fase (wisdom) kebijaksanaan. Fase ini berfokus untuk sosial interaksi dan kehidupan normal bagi pasien penyalahgunaan narkoba, sebagai penemuan jati diri dan keberanian dalam melakukan hal baru serta bijaksana dalam menghadapi permasalahan secara baik dan tidak keluar dari norma. Pada fase ini juga mereka bisa dijadikan panutan untuk pasien penyalahgunaan narkoba lainnya jika sudah berhasil sampai ke fase akhir (roll modelling). Di fase wisdom juga pasien penyalahgunaan narkoba sudah sedikit memiliki kebebasan jika pergi ke Luar Panti Rehabilitasi Karunia Insani Foundation tanpa pengawasan yang ketat sampai ahirnya di nyatakan sembuh dan diperbolehkan pulang, Fase ini biasanya berlangsung 1 bulan. After Care Tahap ini merupakan tahap yang pasien penyalahgunaan narkoba dinyatakan sembuh dan bisa kembali kepada keluarga nya, di tahap ini mereka masih harus mengadakan control selama 4 bulan ke panti rehabilitasi karunia insani, sedangkan 5 bulannya petugas akan mengunjungi pasien penyalahgunaan narkoba ke rumahnya.

Hal ini di sampaikan oleh Adi pasien penyalahgunaan narkoba pada fase serennity " iya awalnya saya bingung sis dengan bahasa-bahasa yang digunakan selama menjalankan pemulihan di panti rehabilitasi ini, karena programnya sangat banyak namun ternyata setelah kita bersama teman yang lain mempelajarinya sekaligus mempratekkannya ternyata tidak sulit, kami juga tidak merasa malu ketika menjalani kegiatan di panti rehabilitasi ini karena

22 Rahman Risaldi, “Petugas Panti Rehabilitasi Karunia Insani Foundation.” 
semua ini pasti ada hikmahnya ". ${ }^{23}$ Hengky yang berada di fase serennity juga menambahkan," saya juga berfikir apasih panti rehabilitasi itu ? tetapi karena kegiatan disini dilakukan bersama teman yang mau sembuh juga jadi saya juga semangat mengikuti kegiatan setiap hari". ${ }^{24}$ Dedy juga menambahkan " kita juga selalu mendapatkan bimbingan yang baik dari semua petugas disini, dan selalu memberi kita semangat untuk sembuh karena kita semua mempunyai cerita yang sama yaitu hancur karena narkoba". ${ }^{25}$

Dari paparan wawancara peneliti terhadap pasien penyalahgunaan narkoba juga sudah dapat dilihat banyak perubahan positif jika dilakukan bersama tanpa ada rasa saling tidak percaya diri, tidak malu jika memang ingin belajar dari awal bersama teman yang lain karena mereka berada dalam cerita yang saa yaitu tentang penyalahgunaan narkoba sehingga penerapan metode therapeutic community menggunakan sistem komunitas atau berkelompok sangat efektif, hal ini karena dengan menerapkan sistem komunitas atau berkelompok maka mereka tidak malu mengakui kesalahan dan tetap saling menguatkan jika memang ingin lepas dari narkoba. adapun penerapan yang dilakukan petugas terlihat teratur dan memiliki arti tersendiri untuk apa kegiatan dilakukan, pasien penyalahgunaan narkoba juga tidak lagi membantah atau memberontak karena emosi yang ada dalam diri pasien penyalahgunaan narkoba sudah terkontrol dengan banyak kegiatan therapeutic community yang dilakukan.

\section{Komunikasi Terapeutik Pasien Penyalahgunaan Narkoba Di Masa Pandemi Covid-19}

Dimasa pandemi covid-19, adanya protokol kesehatan yang diterapkan salah satunya wajib menggunakan masker.ketika menggunakan masker tentu sedikit menggangu cara berkomunikasi karena dalam berkomunikasi harus jelas dalam pengucapan kalimat $\mathrm{A}, \mathrm{I}, \mathrm{U}, \mathrm{E} \mathrm{O}$ serta untuk menditeksi kebohongan yang sifatnya lekat terhadap pasien penyalahgunaan narkoba, untuk mengenali karakter pasien peyalahgunaan narkoba tentu memerlukan pendekatan komunikasi yang baik secara verbal maupun nonverbal adapun komunikasi terapeutik menurut Mukhripah Damaiyanti adalah "segala sesuatu yang memfasilitasi proses penyembuhan, sehingga komunikasi

23 Adi, "Pasien Penyalahgunaan Narkoba Di Fase Serennity," October 31, 2020.

${ }^{24}$ Hengky, "Selaku Pasien Penyalahgunaan Narkoba Di Fase Serennity," October 31, 2020.

25 Dedy, "Pasien Penyalahgunaan Narkoba Di Fase Corge." 
ini merupakan komunikasi yang direncanakan dan dilakukan untuk membantu penyembuhan/pemulihan pasien". ${ }^{26}$

Komunikasi ini tidak hanya dilakukan antar petugas tetapi keluarga yang ikut terlibat karena dalam metode therapeutic community keluarga merupakan motivasi utama bagi pasien penyalahgunaan narkoba terkait permasalahan pandemi covid-19 Panti Rehabilitasi Karunia Insani Foundation membatasi kunjungan keluarga demi menjaga protokol kesehatan.hal ini disampaikan oleh Ari Winarko“ kami juga menganjurkan untuk pembatasan penerimaan orang luar seperti keluarga yang ingin menjenguk pasien penyalahgunaan narkoba dan tetap menggunakan masker, mencuci tangan dan cek suhu sebelum bertemu pasien penyalahgunaan narkoba " ${ }^{27}$ Muslimin juga memberi pendapat " tentu kami pihak dinsos selalu mengingatkan untuk adanya jaga jarak dan terus patuhi protokol kesehatan terutama jika ada orang luar yang memasuki kawasan rehabilitasi". 28

Terkait persoalan di atas, dapat disimpulkan bahwa dalam komunikasi yang dilakukan di masa pandemi covid-19 lebih menuju kepada kunjungan keluarga yang merupakan motivasi utama pasien penyalahgunaan narkoba, maka sebagai solusi nya Panti Rehabilitasi Karunia Insani Foundation memberikan durasi waktu serta mempunyai jadwal secara bergantian dengan keluarga yang ingin visit di hari sabtuminggu dan tetap pada aturan protol kesehatan dan juga dapat menggunakan alat komunikasi handphone jika memang sangat dipentingkan namun tetap ada aturan waktu dan masih dalam pengawasan petugas yang piket. Adapun fase dalam komunikasi terapeutik petugas selama menjalankan proses pemulihan pasien penyalahgunaan narkoba di masa pandemi:

1. Fase Prainteraksi Atau Tahap Persiapan, Fase ini lebih menuju kepada pasien penyalahgunaan narkoba sudah bisa memperkenalkan dan memahami dirinya yang dibantu oleh petugas. Karena sebelum itu petugas telah mendapatkan banyak informasi mengenai diri pasien penyalahgunaan narkoba, seperti yang dikatakan Aldi, " fase pra interaksi ini lebih ke dirinya sudah bisa mengenal identitas dirinya sehingga dia sudah bisa berkomunikasi dengan petugas dan memperkenalkan diri serta dapat menjelaskan kenapa ia terjerumus ? alasan apa hingga menggunakan narkoba ? jadi kita berkomunikasi 2008), 11.

26 1980- Mukhripah Damaiyanti, Komunikasi Terapeutik (Refika Aditama,

27 Ari Winarko, “Imunisasi Dan Kesehatan Khusus Dinas Kesehatan Kab. Musi Rawas."

${ }^{28}$ Muslimin, "Kabid Rehabilitasi Sosial Pada Dinsos Kab. Musi Rawas." 
untuk banyak menggali informasi dari cerita pasien penyalahgunaan narkoba itu sendiri" ${ }^{29}$ Fase pra-interaksi ini petugas lebih banyak mendengarkan bagaimana pasien penyalahgunaan narkoba mengungkapkan dirinya sehingga petugas dapat mengenal karakter dan tau langkah apa yang akan dilakukan selanutnya selama menjalankan pemulihan.

2. Fase Perkenalan Atau Orientasi, Fase perkenalan ini menuju kepada petugas yang memulai meperkenalkan Panti Rehabilitasi Karunia Insani Foundation, dimulai dari apa saja yang harus dilakukan, kegiatan seperti apa untuk proses pemulihan selama 6 bulan bahkan ada peraturan-peraturan yang harus kamu patuhi. Ketika pasien penyalahgunaan narkoba telah mampu memperkenalkan dirinya maka petugas juga mampu memperkenalan tempat yang akan dijadikan rawat inap selama 6 bulan.

3. Fase Kerja Fase ini bisa di sebut juga paska rehab, dimana pasien penyalahgunaan narkoba ketika selesai menjalankan rawat inap maka pasien penyalahgunaan narkoba masih wajib melakukan rawat jalan. Hal ini di upayalan utuk pasien pemyalahgunaan narkoba dapat mengembangkan dirinya ketika ketika menjalankan hidup bersosial dan belajar menghadapi permasalahan secara mandiri. Aldy menambahkan pendapat " biasanya kami melakukan rawat jalan selama kurang lebih 9 bulan, 3 bulan mereka memberi laporan ke sini 6 bulan kami yang mengunjungi dia". ${ }^{30}$ selama menjalankan rawat jalan pasien penyalahgunaan narkoba belum tentu langsung bebas tetapi masih berada dalam pantauan petugas Panti Rehabilitasi Karunia Insani Foundation.

4. Fase Terminasi, Fase ini merupakan akhir dari proses pemulihan pasien penyalahgunaan narkoba, fase ini tidak menentu dalam waktu karena lebih ditunjukan konseling pribadi atar pasien penyalahgunaan narkoba dengan salah satu petugas yang ia jadikan teman untuk mencari solusi seperti, " bro gimana nih sampai sekarang saya belum dapat kerja dan sebagainya". Di sini petuga sebagai teman bisa memberi solusi atas keluhan yang dirasakan pasein penyalahgunaan narkoba setelah selesai di tahap rawat jalan selama 9 bulan.

Komunikasi terapeutik yang digunakan pasien penyalahgunaan narkoba sangatlah dekat dan dibuat senyaman mungkin sehingga pasien penyalahgunaan narkoba tidak mengalami beban saat berada di panti rehabilitasi karunia insani foundation. Hal ini dapat dilihat dari cara

${ }^{29}$ Rahman Risaldi, “Petugas Panti Rehabilitasi Karunia Insani Foundation.”

${ }^{30}$ Ibid. 
panggilan antar petugas dengan pasien penyalahgunaan narkoba yaitu brother dan sister. Wahyu Ningati selaku admin juga menambahkan:

“disini kita tidak menggunakan kata kakak, mbak, atau ibu baik antar petugas dengan pasien hal itu dilarang, sehingga untuk mengakrabkan diri kita menggunakan sis dan bro dengan harap tidak ada perasaan untuk merasa tua dan ingin di hormati, melainkan harus bisa saling menghormati, kita juga disini sebagai petugas menggunakan sis bro untuk panggilan lebih dekatnya jadi secara tidak langsung kita menjadikan diri kita sendiri sebagai contoh untuk pasien penyalahgunaan narkoba" ${ }^{31}$

hal ini disampaikan Adi selaku pasien penyalahgunaan narkoba: "kami juga kadang ada rasa sungkan ketika berhadapan dengan petugas di sini, tetapi mereka memperlakukan kami dengan baik dan pasti punya tujuan yang baik juga untuk kami sehingga kami juga nyaman tidak ada rasa takut, ketika kami mengalami kesulitan kami juga bisa bertemu secara langsung berbicara dengan salah satu petugas yang piket" ${ }^{32}$

Dari paparan wawacara di atas komunikasi terapeutik yang digunakan merupakan pendekatan hubungan baik antar petugas dan pasien penyalahgunaan narkoba yang akan menghasilkan respon secara langsung dan spontan sehingga mereka juga di ajarkan cara mengatur bahasa yang sopan ketika berkomunikasi dengan orang lain atau sesama komunitas, dengan panggilan bro dan sis maka akan terasa nyaman bagi pasien penyalahgunaan narkoba yang memang merupakan tujuan dari komunikasi terapeutik. Dalam penerapan komunikasi terapeutik ini ketika ada permasalah yang terjadi antar komunitas pasien penyalahgunaan narkoba juga selalu di selesaikan bersama dengan cara pasien yang bersangkutan akan ada di tengah lingkaran dan menjelaskan ketidaksukaan yang ia rasakan, hal itu juga disaksikan oleh seluruh pasien penyalahgunaan narkoba karena dalam berkomunikasi mereka melakukan secara terbuka tanpa rahasia antar perorangan.

Dari paparan wawancara di atas dapat disimpulkan bahwa selama masa pandemi covid-19 komunikasi yang terganggu yaitu komunikasi dengan keluarga yang semakin terbatas dan juga ketika mereka berkomunkasi menggunakan masker akan semakin sulit untuk dimengerti sehingga tidak terjadi permasalahan ketika pasien penyalahgunaan narkoba masih dalam lingkungan panti rehabilitasi karunia insani foundation, namun tetap menjaga jarak, menggunakan masker serta kegiatan laporan kesehatan yang dilakukan setiap pagi supaya tetap terpantau oleh petugas. Untuk komunikasi lebih lanjutnya

31 Wahyu Ningati, "Admin Yayasan Panti Rehailitasi Karunia Insani Faoundation," November 1, 2020.

32 Rahman Risaldi, "Petugas Panti Rehabilitasi Karunia Insani Foundation." 
tidak ada rahasia yang terjadi antar petugas dan pasien penyalahgunaan narkoba, komunikasi ini juga dilakukan secara terbuka, bersifat nyaman dan akrab serta ketegasan dalam berbicara sopan.

\section{E. Dukungan Therapeutic Community Pada Pasien Penyalahgunaan Narkoba Dimasa Pandemi Covid-19}

Dukungan serta motivasi merupakan hal yang diterapkan dalam metode therapeutic community karena hal ini sangat berpengaruh kepada kesembuhan psikologis pasien penyalahgunaan narkoba, seperti yang disampaikan oleh Aldi" therapeutic community ini mempunyai dukungan dari berbagai arah, yaitu dari Panti Rehabilitasi Karunia Insani, dari komunitas mereka sendiri dan juga dari keluarga sehingga menjadi imbang". ${ }^{33}$ Adapun dukungan therapeutic community pada Panti Rehabilitasi Karunia Insani Foundation diantaranya;

1. Tekanan Rekan Sebaya

Dukungan ini diberi oleh sesama pasien penyalagunaan narkoba, yang bertujuan saling membantu dalam mengatasi masalah yang dialami, dalam kegiatan ini berisi penguatan untuk mendapatkan feedback, selain itu juga teguran (tekanan rekan sebaya) yang biasanya diberikan ketika pasien melakukan kesalahan dan teman lain tidak sungkan untuk menyebutkan kesalahan. Unsur therapeutic community ini diberikan melalui cerita dan perasaan yang dialami, lalu mendapatkan respon(feedback) dari yang mendengarkan. Dalam kegiatan ini biiasanya dilakukan saat morning meeting.

2. Kunjungan Keluarga (Visit)

therapeutic community tidak bisa terlepas dari pantauan keluarga, karena setiap apapun perkmbangan yang dialami pasien penyalahgunaan narkoba selalu dinformasikan kepada keluarga, lubis mengatakan", kita tidak pernah menutupi apaun yang terjadi dengan pasien penyalahgunaan narkoba karena mereka juga harus tau dan selalu memberi support untuk pasien penyalahgunaan narkoba bisa sembuh, kita juga bisa melihat bagaimana pasien penyalahgunaan narkoba ketika dijenguk keluarga ia akan merasa lebih santay dengan banyak kegiatan yang dilakukan"34. Di saat pandemi covid-19 kunjungan keluarga juga dibatasi dibatasi dan diberi waktu 1 jam, itupun tetap menunggu konfirmasi dari petugas karena dilakukan secara bergantian dengan keluarga lain.

3. Rekreasi (Outing)

33 Ibid.

${ }^{34}$ Kusnadi, "Petugas Panti Rehabilitasi Karunia Insani Foundation." 
Rekreasi ini merupakan penerapan therapeutic community yang dijadikan agenda bulanan Panti Rehabilitasi Karunia Insani Faoundation kepada pasien penyalahgunaan narkoba tanpa terkecuali, selama menjalani program kurang lebih satu bulan diwajibkan adanya kegiatan penyegaran fikiran di luar dengan tujuan ke tempat rekreasi dan dengan pengawasan ketat oleh petugas. Namun ketika pandemi covid-19 kegiatan outing sempat tertunda baru akan dilakukan kembali ketika kondisi sedikit membaik serta tetap mengutamakan protokol kesehatan.

\section{F. KESIMPULAN}

Penerapan metode therapeutic community petugas terhadap pasien penyalahgunaan narkoba dimasa pandemi covid19 berjalan dengan baik dan teratur sesuai daily activity yang dibuat secara rinci dengan kegiatan yang dilakukan dimulai dari pukul 04:30 - 23:00 WIB. Dalam setiap kegiatannya telah diterapkan sesuai dengan tujuan empat struktur program metode therapeutic community seperti, Pembentukan Tingah Laku (Behavioral Menegement Shaping) yang diutamakan pasien penyalahguna narkoba mengetahui semua program kegiatan setiap hari dan mengikuti secara disiplin Penerapan Ini Dilakukan Saat Morning Meeting, Pengendalian Emosi Dan Psikologi (Emotional And Psychological) dilakukan ketika pasien penyalahgunaan narkoba saling menegur dan mengungkapkan ketidaksukaan yang dirasakan antar komunitas namun tetap dalam kondisi aman terkendali jika mereka tidak bisa mengontrol emosi maka akan mendapat hukuman berupa pembelajaran (L.E). penerapan ini dilakukan saat grup circle, Pengembangan Pemikiran Dan Kerohanan (Intelektual And Spiritual) diterapkan ketika pasien penyalahgunaan narkoba mengikuti kegiatan seminar membahas tentang zat adiksi, serta rutin menjalankan puasa senin-kamis, belajar membaca al-quran serta sholat berjamaah tepat waktu, Keterampilan Kerja Dan Keterampilan Bersosial Serta Bertahan Hidup (Vocational And Survival), pasien penyalahgunaan narkoba mendapat sedikit kebebasan dan belajar bersosialisasi dengan masyarakat sekitar tetapi masih dalam pengawasan Adapun fase 
perkembangan pasien penyalahgunaan narkoba yaitu OrientasiSerenity-Corge-Wisdom.

Komunikasi therapeutik di masa pandemi covid-19 lebih diterapkan untuk kunjungan keluarga yang terbatas serta harus memenuhi protokol kesehatan dan ketika ada urusan penting diperbolehkan menggunakan handphone petugas piket, saat kegiatan dilakukan secara tatap muka berdua antar petugas maka tetap menggunakan masker, komunikasi yang dilakukan juga secara terbuka tanpa rahasia dan dibuat senyaman mungkin untuk membangun hubungan baik serta kepercayaan dari pasien penyalahgunaan narkoba.adapun fase dalam komunikasi terapeutik di antaranya, Fase prainteraksi atau tahap persiapan, Fase perkenalan atau orientasi, fase kerja dan fase terminasi. Dukungan therapeutic community di masa pandemi covid-19 mempunyai tiga arah, yaitu tekanan rekan sebaya yang berupa teguran saat melakukan kesalahan dan pemberian respon (feedback) berupa solusi dan motivasi ketika mendengarkan permasalahan dan keluahan antar pasein penyalahgunaan narkoba, kunjunga keluarga (visit) yaitu ketika keluarga mengunjungi pasien penyalahgunaan narkoba untuk melihat perkembangan yang ada di diri mereka meski terbatas namun pasien penyalahgunaan narkoba merasa dan senang lebih santay, terakhir yaitu dari panti rehabilitasi karunia insani mengadakan rekreasi (outing) satu bulan sekali, namun ketika pandemi covid-19 kegiatan ini stop sementara dan akan dilakukan lagi setelah pandemi covid-19 tidak terlalu mengalami peningkatan.

\section{DAFTAR PUSTAKA}

Adi. "Pasien Penyalahgunaan Narkoba Di Fase Serennity," October 31, 2020.

Amalia, Rizki. "Kepuasan Pasien pada Komunikasi Terapeutik Perawat di Ruang Rawat Inap RSUD dr. Pirngadi Medan" (2016). Accessed May 5, 2021. http://repositori.usu.ac.id/handle/123456789/17982.

Ari Winarko. "Imunisasi Dan Kesehatan Khusus Dinas Kesehatan Kab. Musi Rawas," November 5, 2020. 
Cahyandari, Dewi, Shinta Hadiyantina, and Nandharu Ramadhan. "Upaya Pemerintah Daerah dalam Pencegahan dan Penanggulangan Wabah

Virus Korona." Cakrawala: Jurnal Litbang Kebijakan 14, no. 1 (June 5, 2020): 76-81.

Chaplin, James P. Kamus Lengkap Psikologi: James P. Chaplin. Rajawali Press, 1993.

Dedy. “Pasien Penyalahgunaan Narkoba Di Fase Corge," October 31, 2020.

Eleanora, Fransiska Novita. "BAHAYA PENYALAHGUNAAN NARKOBA SERTA USAHA PENCEGAHAN DAN PENANGGULANGANNYA (Suatu Tinjauan Teoritis)." Jurnal Hukum 25, no. 1 (May 5, 2021): 439452.

Hengky. "Selaku Pasien Penyalahgunaan Narkoba Di Fase Serennity," October 31, 2020.

Kusnadi. "Petugas Panti Rehabilitasi Karunia Insani Foundation," October 31, 2020.

Moleong, Lexy J. Metodologi Penelitian Kualitatif. Remadja Karya, 1989.

Mukhripah Damaiyanti, 1980-. Komunikasi Terapeutik. Refika Aditama, 2008.

Muslimin. "Kabid Rehabilitasi Sosial Pada Dinsos Kab. Musi Rawas," October 20, 2020.

NURUL RESTIANA. Metode Therapeutic Community Bagi Pecandu Narkoba Di Panti Sosial Pamardi Putra Yogyakarta, n.d.

Rahman Risaldi. "Petugas Panti Rehabilitasi Karunia Insani Foundation," October 29, 2020.

Said, Nur Rakhmi, Muhammad Thahir Maloko, and Nur Taufiq Sanusi. "METODE THERAPEUTIC COMMUNITY BAGI RESIDEN DI BALAI REHABILITASI BNN BADDOKA MAKASSAR PERSPEKTIF HUKUM ISLAM." Jurnal Al-Qadau: Peradilan dan Hukum Keluarga Islam 6, no. 2 (December 27, 2019): 269-286.

Supriyatno, Helmi. "Darurat PHK Di Tengah Corona." Harian Bhirawa Online, n.d. Accessed May 5, 2021. https://www.harianbhirawa.co.id/darurat-phk-di-tengah-corona/.

Syam, Nina W. Psikologi Sosial Sebagai Akar Ilmu Komunikasi. Simbiosa Rekatama Media, 2012.

Teguh. "Pasien Penyalahgunaan Narkoba Di Fase Corge," October 31, 2020.

Wahyu Ningati. "Admin Yayasan Panti Rehailitasi Karunia Insani Faoundation," November 1, 2020.

Windyaningrum, Rachmawati. "KOMUNIKASI TERAPEUTIK KONSELOR ADIKSI PADA KORBAN PENYALAHGUNAAN NARKOBA DI RUMAH PALMA THERAPEUTIC COMMUNITY KABUPATEN 
BANDUNG BARAT." Jurnal Kajian Komunikasi 2, no. 2 (December 1, 2014): 173-185.

Yolanda, Widyani Tri. "REHABILITASI DI PUSAT PERAWATAN PECANDU NARKOBA DITINJAU DARI KOMUNIKASI TERAPEUTIK." Jurnal Ilmu Komunikasi 5, no. 1 (January 27, 2015): 13-27. 